\title{
Diabetes and Risk of Surgical Site Infection: A Systematic Review and Meta-analysis
}

\author{
Emily T. Martin, MPH, PhD; ${ }^{1}$ Keith S. Kaye, MD, MPH; ${ }^{2}$ Caitlin Knott, PharmD ${ }^{3}$ Huong Nguyen, PharmD; ${ }^{3}$ \\ Maressa Santarossa, PharmD $;{ }^{3}$ Richard Evans, BS; ${ }^{1}$ Elizabeth Bertran, PharmD $;{ }^{3}$ Linda Jaber, PharmD ${ }^{3}$
}

ов естіvе. To determine the independent association between diabetes and surgical site infection (SSI) across multiple surgical procedures. DESIGN. Systematic review and meta-analysis.

Methods. Studies indexed in PubMed published between December 1985 and through July 2015 were identified through the search terms "risk factors" or "glucose" and "surgical site infection." A total of 3,631 abstracts were identified through the initial search terms. Full texts were reviewed for 522 articles. Of these, 94 articles met the criteria for inclusion. Standardized data collection forms were used to extract study-specific estimates for diabetes, blood glucose levels, and body mass index (BMI). A random-effects meta-analysis was used to generate pooled estimates, and meta-regression was used to evaluate specific hypothesized sources of heterogeneity.

RESUlts. The primary outcome was SSI, as defined by the Centers for Disease Control and Prevention surveillance criteria. The overall effect size for the association between diabetes and SSI was odds ratio $(\mathrm{OR})=1.53$ (95\% predictive interval [PI], 1.11-2.12; $\left.\mathrm{I}^{2}, 57.2 \%\right)$. SSI class, study design, or patient BMI did not significantly impact study results in a meta-regression model. The association was higher for cardiac surgery 2.03 (95\% PI, 1.13-4.05) compared with surgeries of other types $(P=.001)$.

CONCLUSIONs. These results support the consideration of diabetes as an independent risk factor for SSIs for multiple surgical procedure types. Continued efforts are needed to improve surgical outcomes for diabetic patients.

Infect. Control Hosp. Epidemiol. 2016;37(1):88-99

Diabetes prevalence is increasing in the United States, ${ }^{1}$ and the appropriate management of patients with diabetes has become increasingly important for the prevention of hospital-acquired infections. Much has been published in recent years about the impact of diabetes on increased rates of surgical site infection (SSI) and the potentially related impact of hyperglycemia on SSI. Surgical site infections are estimated to have an annual financial impact of more than $\$ 3$ billion dollars nationally and are the largest contributor to the overall cost of healthcare-associated infections. ${ }^{2}$ Efforts to reduce the rates of SSIs are becoming more urgent since the introduction of Centers for Medicare and Medicaid Services penalties for hospital readmission rates. An understanding of patient risk factors for SSI is key to these efforts because hospitals with a more vulnerable case mix are more likely to incur readmission penalties. ${ }^{3}$ Furthermore, the substantial prevalence of hospital-associated infections due to antibiotic resistant pathogens ${ }^{4}$ highlights the importance of prevention in individuals at high risk of infection. To gain a greater understanding of the impact of pre-existing diabetes on the incidence of SSI, we performed a meta-analysis of risk factors for SSIs among patients undergoing surgery in US hospitals. We hypothesize that preexisting diabetes is a significant contributor to the development of SSI, independently of hyperglycemia at the time of surgery. Secondarily, we hypothesize that hyperglycemia is itself an independent contributor to increased risk of SSI in surgical patients.

\section{METHODS}

A systematic literature search and meta-analysis was performed following MOOSE guidelines ${ }^{5}$ (Online Supplementary Material).

\section{Data Sources and Searches}

A systematic literature search was performed by 4 study investigators (M.S., C.K., H.N., R.E.) with questions referred to an

Affiliations: 1. Department of Epidemiology, University of Michigan School of Public Health, Ann Arbor, Michigan; 2. Division of Infectious Diseases, Wayne State University and Detroit Medical Center, Detroit, Michigan; 3. Department of Pharmacy Practice, Eugene Applebaum College of Pharmacy and Health Sciences, Wayne State University, Detroit, Michigan.

PREVIOUS PRESENTATION. We presented these findings in part at the 2014 American Diabetes Association annual meeting in San Francisco, California (June 13-17, 2014), and the 2014 Society for Epidemiology Research conference in Seattle, Washington (June 24-27, 2014).

Received May 6, 2015; accepted August 30, 2015; electronically published October 27, 2015

(c) 2015 by The Society for Healthcare Epidemiology of America. All rights reserved. 0899-823X/2016/3701-0014. DOI: 10.1017/ice.2015.249 
adjudication team consisting of the study principal investigator (E.T.M.), 1 investigator with expertise in diabetes epidemiology (L.J.), and 1 investigator with expertise in infectious diseases and infection prevention (K.S.K.). The search was performed in PubMed and EMBASE using combinations of the search terms "risk factors," "diabetes," "glucose," and "surgical site infections" from December 1985 to July 2015 (see Online Supplementary Material: Search Strategy). The starting date of the search, December 1985, was selected to correspond with the wide implementation of the Centers for Disease Control and Prevention (CDC) SSI surveillance guidelines. The search was inclusive of all study designs unless interventional control of glucose during the study prevented an assessment of the association between diabetes and SSI.

\section{Study Selection}

All abstracts were reviewed for eligibility, and the full-article texts of potentially relevant studies were reviewed in depth. Reference lists for all reviewed articles were hand-searched to identify additional eligible articles. Eligibility criteria for study inclusion were the following: (1) original US data; (2) adult participants; (3) utilized the CDC definition for SSIs; and (4) included measurable risk estimates of the association between diabetes and risk of SSI with 95\% confidence intervals or provided adequate information to calculate risk estimates and their 95\% confidence intervals. Review articles, meta-analyses, or non-English studies were excluded (Online Supplementary Material: List of Excluded Studies).

Eligible studies included adult patients undergoing surgical procedures of any type, using NHSN operative procedure categories to define surgical procedures. All comparative study designs (including observational, randomized controlled, retrospective, or prospective studies) were considered for inclusion provided they presented an assessment for the association between diabetes and SSI or the absolute patient numbers needed for the calculation of the measure. Each eligible study was required to include both diabetic and non-diabetic patients in the study population. Multiple publications on the same subject population were reviewed together and were restricted such that each patient population was included only once; this is notable particularly for multiple publications from large surveillance databases (eg, National Surgical Quality Improvement Program; see Online Supplementary Material: Excluded Studies). SSI was defined using criteria specified by the CDC for the purposes of surveillance and reporting.

\section{Data Extraction}

Measures for the association between pre-existing diabetes and SSI were collected from studies that ascertained the presence of diabetes prior to the time of surgery either through the patient's medical record or hemoglobin A1c testing (HbA1c). Assessments of $\mathrm{HbA1c}$ levels were noted; however, not enough studies were identified to merit a separate meta-analysis based on this measure. Measures of the association between peri- or post-operative blood glucose levels were collected from studies that assessed thresholds of glucose levels. Studies that presented only comparisons of mean or median blood glucose levels were excluded from the analysis of peri- or postoperative hyperglycemia due to our inability to define the absolute number of patients with hyperglycemia in the infected and uninfected groups.

Data were abstracted onto standardized forms that included study characteristics, study population, type of SSI (superficial, deep incisional, or organ/space), crude and adjusted estimates, and confidence intervals. For each study, we recorded how diabetes was determined and whether blood glucose was measured prior to, during, or after surgery. Studies were assigned to the following categories based on the type of surgery: obstetrical and gynecological, colorectal, arthroplasty, breast, cardiac, spinal, or other. The abstraction team received training by the principal investigator, including the abstraction of multiple practice cases, before performing data abstraction. A subset of studies included was re-reviewed by 2 study investigators to ensure consistency.

\section{Data Synthesis and Analysis}

The most-adjusted estimate (ie, the adjusted odds ratio for the multivariate regression with the most variables) was used to generate summary estimates. ${ }^{6}$ Summary estimates and predictive intervals were calculated using a DerSimonian and Laird random-effects model for each estimate type. Confidence intervals were used for smaller analyses of diabetes and glucose combined models. The use of random-effects models was based on $\mathrm{I}^{2}$ values exceeding $30 \%$ in each overall fixed-effects analysis. ${ }^{7}$ Funnel plots were generated to assess publication bias (data not shown) (Stata 11, StataCorp, College Station, TX). Sensitivity analysis was performed through the generation of stratified estimates and the use of multiple meta-regression analyses to assess the presence of meta-confounding by study characteristics including surgery type, study type, inclusion of body mass index (BMI) in the adjusted estimate, and diabetes prevalence in the study population. We determined a priori that the primary confounder of concern was BMI.

\section{RES ULT S}

The combined search strategies identified 3,631 abstracts. All of these abstracts were reviewed, and the full texts of 522 articles were reviewed in depth; 3,109 studies were excluded during abstract review (Figure 1), and 428 studies were excluded during full-text review (Online Supplementary Material: List of Excluded Studies).

\section{Meta-analysis for Diabetes and SSI}

A total of 90 studies provided estimates for the association between diabetes and SSI, including 2 studies that provided 


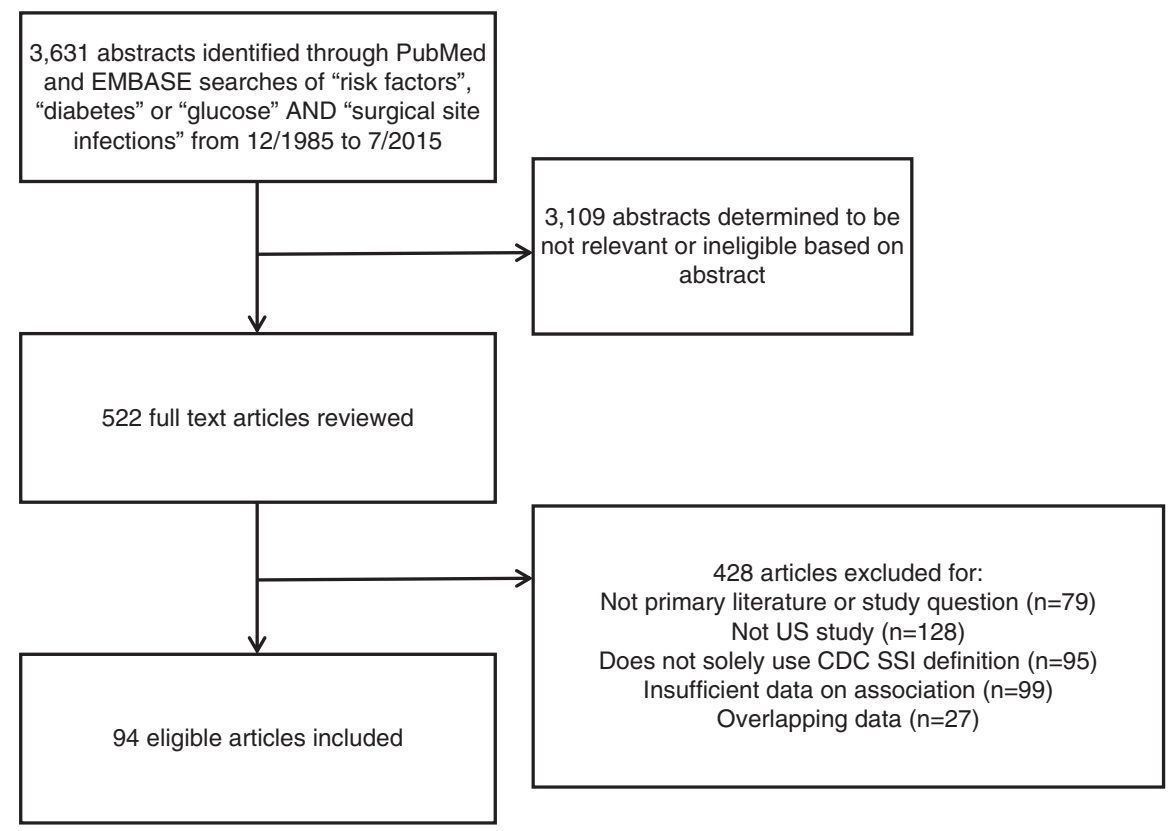

FIGURE 1. Flow diagram of search and selection processes.

multiple estimates (Appendix Table 1). Included studies comprised a total of 866,427 procedures and 32,067 SSIs meeting CDC surveillance criteria. All studies were observational with the exception of 3 randomized controlled trials. We identified 14 studies (16\%) that used prospectively collected data. Diabetes prevalence among included study populations ranged from $2 \%$ to $39 \%$ (median $17 \%$ ). History of diabetes was ascertained by medical record review in all but 2 studies. ${ }^{8,9}$ No included studies differentiated between Type 1 and Type 2 diabetes.

The overall effect size for the association between diabetes and SSI was an odds ratio (OR) of 1.53 (95\% predictive interval [PI], 1.11-2.12; $\mathrm{I}^{2}, 57.2 \%$ ) (Figure 2). Of the included studies, $38(42 \%)$ provided estimates that were adjusted for potential confounding factors. When stratifying the metaanalysis by the availability of crude versus adjusted measures, the effect size was similar (OR, 1.68; 95\% PI, 1.03-2.72; $\mathrm{I}^{2}$, $63.6 \%$ ) for all available crude measures (71 studies); OR was 1.77 (95\% PI, 1.13-2.78); $\mathrm{I}^{2}, 71.1 \%$ ) for all adjusted measures (38 studies). Funnel plots demonstrated greater evidence of potential publication bias for adjusted estimates (data not shown).

\section{Evaluation of Sources of Heterogeneity for Diabetes Estimate}

Study design did not have a significant impact on the overall pooled estimate $(P=.13$ for retrospective vs prospective data collection; $P=.41$ for case-control vs cohort or interventional design). Prevalence of diabetes among study participants was also not a significant source of heterogeneity $(P=.80)$. Among studies presenting estimates restricted to specific SSI classes, the combined OR was 1.95 (95\% PI, 0.65-5.87) for deep SSIs (7 estimates from 6 studies) and the OR was 1.38 (95\% PI, 0.66-2.88) for superficial SSIs (6 estimates from 5 studies).

Among studies reporting on a single surgical category, the most common category was cardiac (15 studies) followed by spinal (14 studies) (Table 1). Estimates by surgery type for the association between diabetes and SSI ranged from 1.16 for colorectal surgeries (95\% PI, $0.93-1.44)$ to 2.03 for cardiac surgeries (95\% PI, 1.13-4.05) (Table 1). Meta-regression for impact of surgery type on the association between diabetes and SSI indicated that the combined SSI effect was higher for cardiac surgery than for all other surgery categories $(P=.001)$. BMI was hypothesized a priori to be an important confounder in the association between diabetes and SSI. Study estimates were stratified according to whether the presented measure controlled for the effect of BMI. The estimate pooled from the 20 studies that controlled for BMI was higher than that pooled from those that did not; however, this factor was not significant when evaluated by meta-regression $(P=.79)$.

\section{Meta-analysis for Blood Glucose and SSI}

In total, 16 studies were available to assess the association between hyperglycemia and SSI, with 10 papers $(n=27,844$ procedures) including pre- or intraoperative assessments of blood glucose levels and 11 papers $(n=32,625$ procedures) including postoperative assessments of blood glucose levels. We observed a wide range in the threshold for defining hyperglycemia. Of 10 studies assessing pre-operative blood glucose, 6 used a threshold of $200 \mathrm{mg} / \mathrm{dL}$, and the remaining 3 studies used thresholds of $125 \mathrm{mg} / \mathrm{dL}$ (2 studies), $180 \mathrm{mg} / \mathrm{dL}$ 


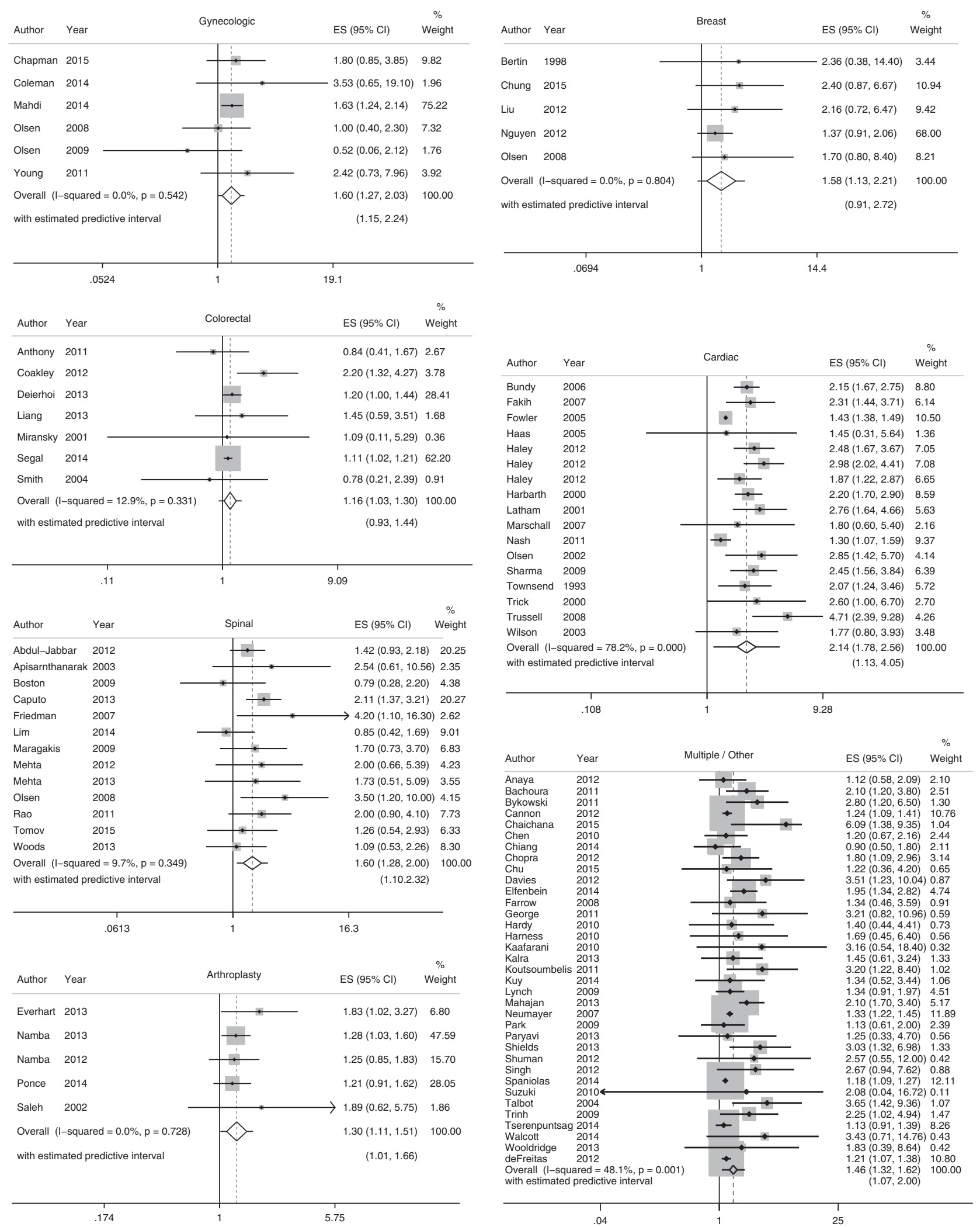

FIGURE 2. Meta-analysis of diabetes and surgical site infection, by surgery type. 
(1 study), and $100 \mathrm{mg} / \mathrm{dL}$ ( 1 study). Of the 11 studies assessing post-operative blood glucose, 5 used thresholds of $200 \mathrm{mg} / \mathrm{dL}$, with the remaining studies using lower thresholds ranging from $125 \mathrm{mg} / \mathrm{dL}$ to $180 \mathrm{mg} / \mathrm{dL}$. One paper presented a composite exposure of pre- or postoperative hyperglycemia, and this estimate was included in both pooled calculations. ${ }^{10}$ The overall estimate for the association between elevated blood glucose and SSI in the pre- or intraoperative period was $\mathrm{OR}=1.88$ (95\% Predictive Interval [PI], 0.66-5.34) (Figure 3). The overall estimate for the association between elevated blood glucose in the post-operative period and SSI was 1.45 (95\% PI, 0.77-3.04) (Figure 4).

Only 3 studies presented multivariate models adjusting for blood glucose levels and diabetes in the same model..$^{8,10,11}$

TABLE 1. Pooled Estimates of the Association between Diabetes and Surgical Site Infection by Surgery Type

\begin{tabular}{lcccr}
\hline Surgery Type & $\begin{array}{c}\text { No. of } \\
\text { Studies }\end{array}$ & $\begin{array}{c}\text { Pooled } \\
\text { Estimate }\end{array}$ & $\begin{array}{c}\text { 95\% } \\
\text { Prediction } \\
\text { Interval }\end{array}$ & $\mathrm{I}^{2}, \%$ \\
\hline Gynecological & 6 & 1.61 & $1.15-2.24$ & 4.0 \\
Colorectal & 7 & 1.16 & $0.93-1.44$ & 9.5 \\
Arthroplasty & 6 & 1.26 & $1.01-1.66$ & 11.7 \\
Breast & 5 & 1.58 & $0.91-2.72$ & 2.7 \\
Cardiac & 15 & 2.03 & $1.13-4.05$ & 22.4 \\
$\begin{array}{l}\text { Spinal } \\
\text { Other/Multiple surgery } \\
\text { types combined }\end{array}$ & 14 & 1.66 & $1.10-2.32$ & 8.1 \\
\hline
\end{tabular}

These studies used thresholds of $\geq 200 \mathrm{mg} / \mathrm{dL}^{8}$ and $\geq 126 \mathrm{mg} / \mathrm{dL}^{11}$ to define elevated preoperative glucose levels or combined preand postoperative thresholds into a single definition. ${ }^{10}$ Pooled estimates of the association between diabetes and SSI, controlling for glucose level was $\mathrm{OR}=2.55$ ( $95 \%$ confidence interval $[\mathrm{CI}$ ], 1.70-3.82). Pooled estimates of the association between elevated glucose level and SSI, controlling for a history of diabetes was $\mathrm{OR}=2.22(95 \% \mathrm{CI}, 1.36-3.60)$.

\section{I S C USS I O N}

\section{Consistency of Included Studies}

We limited our analysis to studies performed at U.S. hospitals after 1985 in an effort to narrow our review to surgeries evaluated with the standard SSI surveillance methods and definitions required by the $\mathrm{CDC}$. We observed some variation in the definitions for hyperglycemia among included studies. Approximately half of the studies used thresholds that met or were more conservative than those proposed by the Society of Thoracic Surgeons ${ }^{12}$ and the American Diabetes Association. ${ }^{13}$ The remaining studies used a slightly higher threshold of $200 \mathrm{mg} / \mathrm{dL}$ to define hyperglycemia, and it is possible that this variation may have introduced heterogeneity into our combined estimates for hyperglycemia.

Almost all included studies used medical record review to assess a patient's reported history of diabetes. This data may be prone to error and may not reliably identify all patients with diabetes or assess the degree to which an individual patient's



FIGURE 3. Meta-analysis of pre-operative hyperglycemia and surgical site infection. 


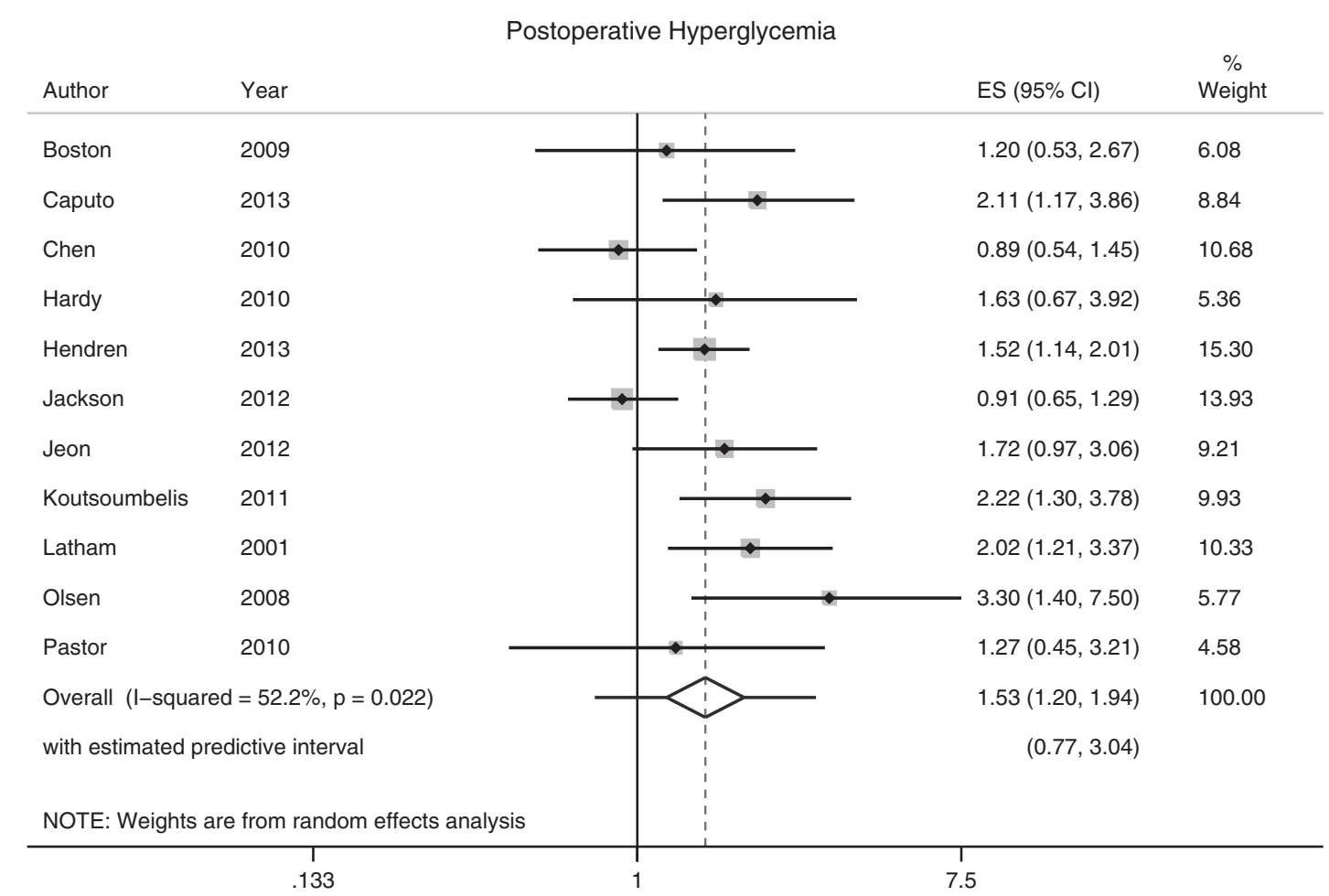

FIGURE 4. Meta-analysis of post-operative hyperglycemia and surgical site infection.

diabetic condition is adequately controlled. Likewise, the assessment of diabetes for use with the revised surgical risk index from the Centers of Disease Control does not recommend the use of $\mathrm{HbAlc}$ or other markers of severity of diabetes to gather risk information. ${ }^{14}$

\section{Generalizability of Study Estimate}

Our requirement that all studies be based in the United States excluded available data from other countries; however, it allowed us to strictly assess SSIs using CDC definitions from hospitals participating in standardized surveillance procedures. While specific quality ratings were not performed for each study, we explored several potential sources of heterogeneity in our pooled estimates through the use of meta-regression. Our stratum-specific estimates show a very consistent association between diabetes and SSIs across categories, including study characteristics, and after controlling for BMI. We were unable to assess variation due to SSI surveillance practices in different hospitals. While studies using active follow-up protocols would be expected to have increased SSI rates, we do not expect that this effect would be differential by diabetes status. Our pooled estimates are based on the use of the most adjusted estimate available in each study. ${ }^{6}$ To assess the impact of this rule, summary estimates were generated separately for all available crude effects and all available adjusted effects, and the findings in these models were similar to the most-adjusted models.
The funnel plot for the adjusted estimates indicates the possible presence of publication bias for these estimates in this body of literature (data not shown). This bias is likely due to the tendency of authors to publish only those variables that are significant in multivariate analyses. Given our findings of an association between diabetes and SSI in almost every category of surgery type, it is likely that non-significant findings for diabetes in smaller studies may be due to insufficient sample size in individual studies, rather than a lack of underlying impact. For that reason, it may be prudent to include diabetes as an a priori hypothesized risk factor in future studies with the inclusion of diabetes in adjusted models for risk of SSIs.

\section{Interpretation of Findings}

Our finding of increased SSI among patients with diabetes was consistent across surgery types, with the exception of obstetrical and gynecological surgery which was based on 2 studies conducted at the same hospital. The surgery-specific findings were statistically significant for arthroplasty, breast, cardiac, and spinal surgeries; the actual pooled estimate was highest among patients undergoing cardiac surgery. These findings contrast with the analysis of National Healthcare Safety Network data that served as the basis for the revised procedure-specific SSI risk-adjustment calculations. This analysis found diabetes to only be associated with SSI for spinal fusion or refusion. ${ }^{14}$ In patients with diabetes receiving 
colorectal resection, glucose levels were consistently higher in patients with an SSI compared with uninfected patients, even when mean glucose levels were below $200 \mathrm{mg} / \mathrm{dL}$ in those with or without SSI. ${ }^{15}$ Similar findings have been reported in patients undergoing laminectomy. ${ }^{16}$ Elevated blood glucose has been found to be associated with increased rates of infection in orthopaedic spine surgery, ${ }^{17}$ cardiac surgery, ${ }^{11,18,19}$ and colorectal and bariatric surgery ${ }^{20}$; however, this association has not been consistently found. ${ }^{21,22}$

The notion that diabetes is a significant contributor to SSI risk through mechanisms other than hyperglycemia at the time of surgery is supported by the few studies that included both glucose levels and history of diabetes in the multivariate models. In the pooled estimate from these studies, the magnitude of the effect of diabetes was stronger than that of our primary analysis that included all eligible studies. The results of an interventional study by Trussel et $\mathrm{al}^{23}$ corroborates this finding. Diabetes remained a significant risk factor for SSI with an odds ratio of 4.71 despite the implementation of a patient care pathway targeting glucose control during the time of surgery and resulting in successfully reducing the overall rates of infection. However, we identified few studies suitable for analysis of potential independent effects of diabetes and hyperglycemia on SSI.

\section{CONCLUSIONS}

In our study, we found a significant association between diabetes and SSI that was consistent across multiple types of surgeries and after controlling for BMI. While we also confirmed an association between both pre- and post-operative hyperglycemia and SSI, history of diabetes remained a significant risk factor in meta-analyses of studies that controlled for hyperglycemia.

Furthermore, we found diabetes to be a significant contributor to the risk of SSIs, potentially beyond its role in causing hyperglycemia during or after surgery. The reasons for this finding are unclear. It is possible that diabetes is a marker for other conditions that may put a patient at risk of infection, including vascular changes and white blood cell dysfunction. In addition, the occurrence of perioperative hyperglycemia and subsequent immune suppression is affected by the complex contributions of factors in addition to the diabetic history of the patient, including physiologic stressors and exogenous glucose administration. ${ }^{24}$ Although we were able to assess the confounding effect of body mass index and found no effect on our conclusions, our ability to fully assess potential confounders in the current meta-analysis is limited by the variables assessed in the original studies. However, the most adjusted estimate from each study was used in the final analysis, which should benefit from control of other confounding variables at the individual study level. Our findings point to several directions for future research. Few studies have assessed whether a more detailed assessment of diabetes severity would improve the management of SSI risk in these patients. Secondly, few studies address the cause of the infection, and thus we are unable to rule out whether the increased risk of SSI among diabetics is related to differences in bacterial etiology.

Overall, these results support the consideration of diabetes as an independent risk factor for SSIs for multiple procedure types and continued efforts are needed to improve surgical outcomes for diabetic patients.

\section{ACKNOWLEDGMENTS}

Financial support. This work was supported by the National Institutes of Health (grant no. K01AI099006 to E.T.M.).

Potential conflicts of interest. All authors report no conflicts of interest relevant to this article.

Address correspondence to Emily T. Martin, MPH, PhD, Department of Epidemiology, University of Michigan School of Public Health, 1415 Washington Heights, Ann Arbor, Michigan, USA 48109-2029 (etmartin@umich.edu).

\section{SUPPLEMENTARY MATERIAL}

To view supplementary material for this article, please visit http://dx.doi.org/10.1017/ice.2015.249

\section{REFERENCES}

1. Cheng YJ, Imperatore G, Geiss LS, Wang J, Saydah SH, Cowie CC, et al. Secular changes in the age-specific prevalence of diabetes among US adults: 1988-2010. Diabetes Care 2013;36: 2690-2696.

2. Zimlichman E, Henderson D, Tamir O, Franz C, Song P, Yamin CK, et al. Health care-associated infections: a meta-analysis of costs and financial impact on the US health care system. JAMA Intern Med 2013;173:2039-2046.

3. Joynt KE, Jha AK. Characteristics of hospitals receiving penalties under the Hospital Readmissions Reduction Program. JAMA 2013;309:342-343.

4. Sievert DM, Ricks P, Edwards JR, Schneider A, Patel J, Srinivasan A, et al. Antimicrobial-resistant pathogens associated with healthcareassociated infections: summary of data reported to the National Healthcare Safety Network at the Centers for Disease Control and Prevention, 2009-2010. Infect Control Hospital Epidemiol 2013;34:1-14.

5. Stroup DF, Berlin JA, Morton SC, Olkin I, Williamson GD, Rennie D, et al. Meta-analysis of observational studies in epidemiology: a proposal for reporting. Meta-analysis Of Observational Studies in Epidemiology (MOOSE) group. JAMA 2000;283:2008-2012.

6. Petitti DB. Meta-analysis, decision analysis, and cost-effectiveness analysis: methods for quantitative synthesis in medicine. 2nd ed. New York: Oxford University Press; 2000. x, 306 p.

7. Higgins JPT, Green S, Cochrane Collaboration. Cochrane handbook for systematic reviews of interventions. Chichester, England; Hoboken, NJ: Wiley-Blackwell; 2008. xxi, 649 p.

8. Latham R, Lancaster AD, Covington JF, Pirolo JS, Thomas CS, Jr. The association of diabetes and glucose control with surgical-site infections among cardiothoracic surgery patients. Infect Control Hospital Epidemiol 2001;22:607-612. 
9. Liang MK, Li LT, Avellaneda A, Moffett JM, Hicks SC, Awad SS. Outcomes and predictors of incisional surgical site infection in stoma reversal. JAMA Surg 2013;148:183-189.

10. Olsen MA, Nepple JJ, Riew KD, Lenke LG, Bridwell KH, Mayfield J, et al. Risk factors for surgical site infection following orthopaedic spinal operations. J Bone Joint Surg Am 2008;90:62-69.

11. Wilson SJ, Sexton DJ. Elevated preoperative fasting serum glucose levels increase the risk of postoperative mediastinitis in patients undergoing open heart surgery. Infect Control Hospital Epidemiol 2003;24:776-778.

12. Lazar HL, McDonnell M, Chipkin SR, Furnary AP, Engelman RM, Sadhu AR, et al. The Society of Thoracic Surgeons practice guideline series: Blood glucose management during adult cardiac surgery. Ann Thorac Surg 2009;87:663-669.

13. American Diabetes A. Standards of medical care in diabetes2008. Diabetes Care 2008;31:S12-S54.

14. Mu Y, Edwards JR, Horan TC, Berrios-Torres SI, Fridkin SK. Improving risk-adjusted measures of surgical site infection for the national healthcare safety network. Infect Control Hospital Epidemiol 2011;32:970-986.

15. Sehgal R, Berg A, Figueroa R, Poritz LS, McKenna KJ, Stewart DB, et al. Risk factors for surgical site infections after colorectal resection in diabetic patients. J Am Coll Surg 2011;212:29-34.

16. Friedman ND, Sexton DJ, Connelly SM, Kaye KS. Risk factors for surgical site infection complicating laminectomy. Infect Control Hospital Epidemiol 2007;28:1060-1065.

17. Caputo AM, Dobbertien RP, Ferranti JM, Brown CR, Michael KW, Richardson WJ. Risk factors for infection after orthopaedic spine surgery at a high-volume institution. J Surg Orthopaed Adv 2013;22:295-298.

18. Furnary AP, Zerr KJ, Grunkemeier GL, Starr A. Continuous intravenous insulin infusion reduces the incidence of deep sternal wound infection in diabetic patients after cardiac surgical procedures. Ann Thorac Surg 1999;67:352-360; discussion 60-62.

19. Zerr KJ, Furnary AP, Grunkemeier GL, Bookin S, Kanhere V, Starr A. Glucose control lowers the risk of wound infection in diabetics after open heart operations. Ann Thorac Surg 1997;63: 356-361.

20. Kwon S, Thompson R, Dellinger P, Yanez D, Farrohki E, Flum D. Importance of perioperative glycemic control in general surgery: a report from the Surgical Care and Outcomes Assessment Program. Ann Surg 2013;257:8-14.

21. Hardy SJ, Nowacki AS, Bertin M, Weil RJ. Absence of an association between glucose levels and surgical site infections in patients undergoing craniotomies for brain tumors. J Neurosurg 2010;113:161-166.

22. Jeon CY, Furuya EY, Berman MF, Larson EL. The role of pre-operative and post-operative glucose control in surgical-site infections and mortality. PloS One 2012;7:e45616.

23. Trussell J, Gerkin R, Coates B, Brandenberger J, Tibi P, Keuth J, et al. Impact of a patient care pathway protocol on surgical site infection rates in cardiothoracic surgery patients. Am J Surg 2008; 196:883-889; discussion 9.

24. Russo N. Perioperative glycemic control. Anesthesiol Clin 2012;30:445-466.

25. Abdul-Jabbar A, Takemoto S, Weber MH, Hu SS, Mummaneni PV, Deviren V, et al. Surgical site infection in spinal surgery: description of surgical and patient-based risk factors for postoperative infection using administrative claims data. Spine 2012;37:1340-1345.
26. Anaya DA, Cormier JN, Xing Y, Koller P, Gaido L, Hadfield D, et al. Development and validation of a novel stratification tool for identifying cancer patients at increased risk of surgical site infection. Ann Surg 2012;255:134-139.

27. Anthony T, Murray BW, Sum-Ping JT, Lenkovsky F, Vornik VD, Parker BJ, et al. Evaluating an evidence-based bundle for preventing surgical site infection: a randomized trial. Arch Surg 2011;146:263-269.

28. Apisarnthanarak A, Jones $\mathrm{M}$, Waterman BM, Carroll CM, Bernardi R, Fraser VJ. Risk factors for spinal surgical-site infections in a community hospital: a case-control study. Infect Control Hospital Epidemiol 2003;24:31-36.

29. Bachoura A, Guitton TG, Smith RM, Vrahas MS, Zurakowski D, Ring D. Infirmity and injury complexity are risk factors for surgical-site infection after operative fracture care. Clin Orthopaed Rel Res 2011;469:2621-2630.

30. Bertin ML, Crowe J, Gordon SM. Determinants of surgical site infection after breast surgery. Am J Infect Control 1998;26: 61-65.

31. Boston KM, Baraniuk S, O’Heron S, Murray KO. Risk factors for spinal surgical site infection, Houston, Texas. Infect Control Hospital Epidemiol 2009;30:884-889.

32. Bundy JK, Gonzalez VR, Barnard BM, Hardy RJ, DuPont HL. Gender risk differences for surgical site infections among a primary coronary artery bypass graft surgery cohort: 1995-1998. Am J Infect Control 2006;34:114-121.

33. Bykowski MR, Sivak WN, Cray J, Buterbaugh G, Imbriglia JE, Lee WP. Assessing the impact of antibiotic prophylaxis in outpatient elective hand surgery: a single-center, retrospective review of 8,850 cases. J Hand Surg 2011;36:1741-1747.

34. Cannon JA, Altom LK, Deierhoi RJ, Morris M, Richman JS, Vick $\mathrm{CC}$, et al. Preoperative oral antibiotics reduce surgical site infection following elective colorectal resections. Dis Colon Rectum 2012;55:1160-1166.

35. Chaichana KL, Kone L, Bettegowda C, Weingart JD, Olivi A, Lim M, et al. Risk of surgical site infection in 401 consecutive patients with glioblastoma with and without carmustine wafer implantation. Neurol Res 2015;37:717-726.

36. Chapman JS, Roddy E, Westhoff G, Simons E, Brooks R, Ueda S, et al. Post-operative enteral immunonutrition for gynecologic oncology patients undergoing laparotomy decreases wound complications. Gynecol Oncol 2015;137:523-528.

37. Chen S, Anderson MV, Cheng WK, Wongworawat MD. Diabetes associated with increased surgical site infections in spinal arthrodesis. Clin OrthopaedRel Res 2009;467:1670-1673.

38. Chen TY, Anderson DJ, Chopra T, Choi Y, Schmader KE, Kaye KS. Poor functional status is an independent predictor of surgical site infections due to methicillin-resistant Staphylococcus aureus in older adults. J Am Geriatr Soc 2010;58:527-532.

39. Chiang HY, Kamath AS, Pottinger JM, Greenlee JDW, Howard IMA, Cavanaugh JE, et al. Risk factors and outcomes associated with surgical site infections after craniotomy or craniectomy clinical article. J Neurosurg 2014;120:509-521.

40. Chopra T, Marchaim D, Lynch Y, Kosmidis C, Zhao JJ, Dhar S, et al. Epidemiology and outcomes associated with surgical site infection following bariatric surgery. Am J Infect Control 2012;40:815-819.

41. Chu DI, Schlieve CR, Colibaseanu DT, Simpson PJ, Wagie AE, Cima RR, et al. Surgical site infections (SSIs) after stoma 
reversal (SR): risk factors, implications, and protective strategies. J Gastrointest Surg Tract 2015;19:327-334.

42. Chung CU, Wink JD, Nelson JA, Fischer JP, Serletti JM, Kanchwala SK. Surgical site infections after free flap breast reconstruction: an analysis of 2,899 patients from the ACS-NSQIP datasets. J Reconstruct Microsurg 2015;31:434-441.

43. Coakley BA, Divino CM. Identifying factors predictive of surgical-site infections after colectomy for fulminant ulcerative colitis. Am Surgeon 2012;78:481-484.

44. Coleman JS, Green I, Scheib S, Sewell C, Lee JM, Anderson J. Surgical site infections after hysterectomy among HIV-infected women in the HAART era: a single institution's experience from 1999-2012. Am J Obstet Gynecol 2014;210:117.e1-117.e7.

45. Davies SW, Turza KC, Sawyer RG, Schirmer BD, Hallowell PT. A comparative analysis between laparoscopic and open ventral hernia repair at a tertiary care center. Am Surgeon 2012;78:888-892.

46. deFreitas DJ, Kasirajan K, Ricotta JJ 2nd, Veeraswamy RK, Corriere MA. Preoperative inpatient hospitalization and risk of perioperative infection following elective vascular procedures. Ann Vasc Surg 2012;26:46-54.

47. Deierhoi RJ, Dawes LG, Vick C, Itani KMF, Hawn MT. Choice of intravenous antibiotic prophylaxis for colorectal surgery does matter. J Am Coll Surg 2013;217:763-769.

48. Elfenbein DM, Schneider DF, Chen H, Sippel RS. Surgical site infection after thyroidectomy: a rare but significant complication. J Surg Res 2014;190:170-176.

49. Everhart JS, Altneu E, Calhoun JH. Medical comorbidities are independent preoperative risk factors for surgical infection after total joint arthroplasty. Clin Orthopaed Rel Res 2013;471:3112-3119.

50. Fakih MG, Sharma M, Khatib R, Berriel-Cass D, Meisner S, Harrington $S$, et al. Increase in the rate of sternal surgical site infection after coronary artery bypass graft: a marker of higher severity of illness. Infect Control Hospital Epidemiol 2007;28:655-660.

51. Farrow B, Awad S, Berger DH, Albo D, Lee L, Subramanian A, et al. More than 150 consecutive open umbilical hernia repairs in a major Veterans Administration Medical Center. Am J Surg 2008;196:647-651.

52. Fowler VG Jr., O’Brien SM, Muhlbaier LH, Corey GR, Ferguson TB, Peterson ED. Clinical predictors of major infections after cardiac surgery. Circulation 2005;112:I358-I365.

53. George AK, Srinivasan AK, Cho J, Sadek MA, Kavoussi LR. Surgical site infection rates following laparoscopic urological procedures. J Urol 2011;185:1289-1293.

54. Haas JP, Evans AM, Preston KE, Larson EL. Risk factors for surgical site infection after cardiac surgery: the role of endogenous flora. Heart Lung 2005;34:108-114.

55. Haley VB, Van Antwerpen C, Tsivitis M, Doughty D, Gase KA, Hazamy $\mathrm{P}$, et al. Risk factors for coronary artery bypass graft chest surgical site infections in New York State, 2008. Am J Infect Control 2012;40:22-28.

56. Harbarth S, Samore MH, Lichtenberg D, Carmeli Y. Prolonged antibiotic prophylaxis after cardiovascular surgery and its effect on surgical site infections and antimicrobial resistance. Circulation 2000;101:2916-2921.

57. Harness NG, Inacio MC, Pfeil FF, Paxton LW. Rate of infection after carpal tunnel release surgery and effect of antibiotic prophylaxis. J Hand Surg 2010;35:189-196.

58. Hellinger WC, Heckman MG, Crook JE, Taner CB, Willingham DL, Diehl NN, et al. Association of surgeon with surgical site infection after liver transplantation. Am J Transplant 2011;11: 1877-1884.

59. Hendren S, Fritze D, Banerjee M, Kubus J, Cleary RK, Englesbe MJ, et al. Antibiotic choice is independently associated with risk of surgical site infection after colectomy: a population-based cohort study. Ann Surg 2013;257:469-475.

60. Jackson RS, Amdur RL, White JC, Macsata RA. Hyperglycemia is associated with increased risk of morbidity and mortality after colectomy for cancer. J Am Coll Surg 2012;214:68-80.

61. Kaafarani HMA, Kaufman D, Reda D, Itani KMF. Predictors of surgical site infection in laparoscopic and open ventral incisional herniorrhaphy. J Surg Res 2010;163:229-234.

62. Kalra L, Camacho F, Whitener CJ, Du P, Miller M, Zalonis C, et al. Risk of methicillin-resistant Staphylococcus aureus surgical site infection in patients with nasal MRSA colonization. Am J Infect Control 2013;41:1253-1257.

63. Koutsoumbelis S, Hughes AP, Girardi FP, Cammisa FP Jr., Finerty EA, Nguyen JT, et al. Risk factors for postoperative infection following posterior lumbar instrumented arthrodesis. J Bone Joint Surg Am 2011;93:1627-1633.

64. Kuy S, Dua A, Desai S, Dua A, Patel B, Tondravi N, et al. Surgical site infections after lower extremity revascularization procedures involving groin incisions. Ann Vasc Surg 2014;28:53-58.

65. Lim S, Edelstein AI, Patel AA, Kim BD, Kim JY. Risk factors for postoperative infections following single level lumbar fusion surgery. Spine 2014 [Epub ahead of print].

66. Liu DZ, Dubbins JA, Louie O, Said HK, Neligan PC, Mathes DW. Duration of antibiotics after microsurgical breast reconstruction does not change surgical infection rate. Plastic Reconstr Surg 2012;129:362-367.

67. Lovecchio F, Beal M, Kwasny M, Manning D. Do patients with insulin-dependent and noninsulin-dependent diabetes have different risks for complications after arthroplasty? Clin Orthopaed Rel Res 2014;472:3570-3575.

68. Lynch RJ, Ranney DN, Shijie C, Lee DS, Samala N, Englesbe MJ. Obesity, surgical site infection, and outcome following renal transplantation. Ann Surg 2009;250:1014-1020.

69. Mahajan SN, Ariza-Heredia EJ, Rolston KV, Graviss LS, Feig BW, Aloia TA, et al. Perioperative antimicrobial prophylaxis for intraabdominal surgery in patients with cancer: a retrospective study comparing ertapenem and nonertapenem antibiotics. Ann Surg Oncol 2014;21:513-519.

70. Mahdi H, Gojayev A, Buechel M, Knight J, SanMarco J, Lockhart D, et al. Surgical site infection in women undergoing surgery for gynecologic cancer. Int J Gynecol Cancer 2014;24:779-786.

71. Maragakis LL, Cosgrove SE, Martinez EA, Tucker MG, Cohen DB, Perl TM. Intraoperative fraction of inspired oxygen is a modifiable risk factor for surgical site infection after spinal surgery. Anesthesiology 2009;110:556-562.

72. Marschall J, Hopkins-Broyles D, Jones M, Fraser VJ, Warren DK. Case-control study of surgical site infections associated with pacemakers and implantable cardioverter-defibrillators. Infect Control Hospital Epidemiol 2007;28:1299-1304.

73. Mehta AI, Babu R, Karikari IO, Grunch B, Agarwal VJ, Owens TR, et al. 2012 Young Investigator Award winner: the distribution of body mass as a significant risk factor for lumbar spinal fusion postoperative infections. Spine 2012;37:1652-1656.

74. Mehta AI, Babu R, Sharma R, Karikari IO, Grunch BH, Owens TR, et al. Thickness of subcutaneous fat as a risk factor for 
infection in cervical spine fusion surgery. J Bone Joint Surg Am 2013;95:323-328.

75. Miransky J, Ruo L, Nicoletta S, Eagan J, Sepkowitz K, Margetson N, et al. Impact of a surgeon-trained observer on accuracy of colorectal surgical site infection rates. Dis Colon Rectum 2001;44:1100-1105.

76. Namba RS, Inacio MC, Paxton EW. Risk factors associated with surgical site infection in 30,491 primary total hip replacements. J Bone Joint Surg Brit 2012;94:1330-1338.

77. Namba RS, Inacio MC, Paxton EW. Risk factors associated with deep surgical site infections after primary total knee arthroplasty: an analysis of 56,216 knees. J Bone Joint Surg Am 2013;95:775-782.

78. Nash MC, Strom JA, Pathak EB. Prevalence of major infections and adverse outcomes among hospitalized. ST-elevation myocardial infarction patients in Florida, 2006. BMC Cardiovasc Disord 2011;11:69.

79. Neumayer L, Hosokawa P, Itani K, El-Tamer M, Henderson WG, Khuri SF. Multivariable predictors of postoperative surgical site infection after general and vascular surgery: results from the patient safety in surgery study. J Am Coll Surg 2007;204:1178-1187.

80. Nguyen TJ, Costa MA, Vidar EN, Shahabi A, Peric M, Hernandez $\mathrm{AM}$, et al. Effect of immediate reconstruction on postmastectomy surgical site infection. Ann Surg 2012;256:326-333.

81. Olsen MA, Lock-Buckley P, Hopkins D, Polish LB, Sundt TM, Fraser VJ. The risk factors for deep and superficial chest surgicalsite infections after coronary artery bypass graft surgery are different. J Thorac Cardiovasc Surg 2002;124:136-145.

82. Olsen MA, Lefta M, Dietz JR, Brandt KE, Aft R, Matthews R, et al. Risk factors for surgical site infection after major breast operation. J Am Coll Surg 2008;207:326-335.

83. Olsen MA, Butler AM, Willers DM, Devkota P, Gross GA, Fraser VJ. Risk factors for surgical site infection after low transverse cesarean section. Infect Control Hospital Epidemiol 2008;29: 477-484; discussion 485-486.

84. Olsen MA, Higham-Kessler J, Yokoe DS, Butler AM, Vostok J, Stevenson KB, et al. Developing a risk stratification model for surgical site infection after abdominal hysterectomy. Infect Control Hospital Epidemiol 2009;30:1077-1083.

85. Park C, Hsu C, Neelakanta G, Nourmand H, Braunfeld M, Wray C, et al. Severe intraoperative hyperglycemia is independently associated with surgical site infection after liver transplantation. Transplantation 2009;87:1031-1036.

86. Paryavi E, Stall A, Gupta R, Scharfstein DO, Castillo RC, Zadnik M, et al. Predictive model for surgical site infection risk after surgery for high-energy lower-extremity fractures: development of the risk of infection in orthopedic trauma surgery score. J Trauma Acute Care Surg 2013;74:1521-1527.

87. Pastor C, Baek JH, Varma MG, Kim E, Indorf LA, Garcia-Aguilar J. Validation of the risk index category as a predictor of surgical site infection in elective colorectal surgery. Dis Colon Rectum 2010;53:721-727.

88. Ponce B, Raines BT, Reed RD, Vick C, Richman J, Hawn M. Surgical site infection after arthroplasty: comparative effectiveness of prophylactic antibiotics: do surgical care improvement project guidelines need to be updated? J Bone Joint Surg Am 2014;96:970-977.

89. Rao SB, Vasquez G, Harrop J, Maltenfort M, Stein N, Kaliyadan G, et al. Risk factors for surgical site infections following spinal fusion procedures: a case-control study. Clin Infect Dis 2011;53:686-692.
90. Saleh K, Olson M, Resig S, Bershadsky B, Kuskowski M, Gioe T, et al. Predictors of wound infection in hip and knee joint replacement: results from a 20-year surveillance program. J Orthopaed Res 2002;20:506-515.

91. Segal CG, Waller DK, Tilley B, Piller L, Bilimoria K. An evaluation of differences in risk factors for individual types of surgical site infections after colon surgery. Surgery 2014;156:1253-1260.

92. Senekjian L, Nirula R. Tailoring the operative approach for appendicitis to the patient: a prediction model from national surgical quality improvement program data. J Am Coll Surg 2013;216:34-40.

93. Sharma M, Fakih MG, Berriel-Cass D, Meisner S, Saravolatz L, Khatib R. Harvest surgical site infection following coronary artery bypass grafting: risk factors, microbiology, and outcomes. Am J Infect Control 2009;37:653-657.

94. Shields RK, Clancy CJ, Minces LR, Shigemura N, Kwak EJ, Silveira FP, et al. Epidemiology and outcomes of deep surgical site infections following lung transplantation. Am J Transplant 2013;13:2137-2145.

95. Shuman AG, Shuman EK, Hauff SJ, Fernandes LL, Light E, Chenoweth CE, et al. Preoperative topical antimicrobial decolonization in head and neck surgery. Laryngoscope 2012;122:2454-2460.

96. Singh R, Mesh CL, Aryaie A, Dwivedi AK, Marsden B, Shukla R, et al. Benefit of a single dose of preoperative antibiotic on surgical site infection in varicose vein surgery. Ann Vasc Surg 2012;26:612-619.

97. Smith RL, Bohl JK, McElearney ST, Friel CM, Barclay MM, Sawyer RG, et al. Wound infection after elective colorectal resection. Ann Surg 2004;239:599-605.

98. Spaniolas K, Kasten KR, Mozer AB, Sippey ME, Chapman WH, Pories WJ, et al. Synchronous ventral hernia repair in patients undergoing bariatric surgery. Obes Surg 2015;25:1864-1868.

99. Suzuki T, Morgan SJ, Smith WR, Stahel PF, Gillani SA, Hak DJ. Postoperative surgical site infection following acetabular fracture fixation. Injury 2010;41:396-399.

100. Talbot TR, D’Agata EM, Brinsko V, Lee B, Speroff T, Schaffner W. Perioperative blood transfusion is predictive of poststernotomy surgical site infection: marker for morbidity or true immunosuppressant? Clin Infect Dis 2004;38:1378-1382.

101. Tomov M, Mitsunaga L, Durbin-Johnson B, Nallur D, Roberto R. Reducing surgical site infection in spinal surgery with betadine irrigation and intrawound vancomycin powder. Spine 2015;40:491-499.

102. Townsend TR, Reitz BA, Bilker WB, Bartlett JG. Clinical trial of cefamandole, cefazolin, and cefuroxime for antibiotic prophylaxis in cardiac operations. J Thorac Cardiovasc Surg 1993;106: 664-670.

103. Trick WE, Scheckler WE, Tokars JI, Jones KC, Smith EM, Reppen ML, et al. Risk factors for radial artery harvest site infection following coronary artery bypass graft surgery. Clin Infect Dis 2000;30:270-275.

104. Trinh JV, Chen LF, Sexton DJ, Anderson DJ. Risk factors for gram-negative bacterial surgical site infection: do allergies to antibiotics increase risk? Infect Control Hospital Epidemiol 2009;30:440-446.

105. Tserenpuntsag B, Haley V, Van Antwerpen C, Doughty D, Gase KA, Hazamy PA, et al. Surgical site infection risk factors identified for patients undergoing colon procedures, New York State 2009-2010. Infect Control Hospital Epidemiol 2014;35: 1006-1012. 
106. Walcott BP, Neal JB, Sheth SA, Kahle KT, Eskandar EN, Coumans JV, et al. The incidence of complications in elective cranial neurosurgery associated with dural closure material. J Neurosurg 2014;120:278-284.

107. Woods BI, Rosario BL, Chen A, Waters JH, Donaldson W 3rd, Kang J, et al. The association between perioperative allogeneic transfusion volume and postoperative infection in patients following lumbar spine surgery. J Bone Joint Surg Am 2013;95: 2105-2110.
108. Wooldridge AN, Kolovich GP, Crist MK, Mayerson JL, Scharschmidt TJ. Predictors of local recurrence in high-grade soft tissue sarcomas: hydrogen peroxide as a local adjuvant. Orthopedics 2013;36:e207-e215.

109. Young B, Ng TM, Teng C, Ang B, Tai HY, Lye DC. Nonconcordance with surgical site infection prevention guidelines and rates of surgical site infections for general surgical, neurological, and orthopedic procedures. Antimicrob Agents Chemother 2011;55:4659-4663.

A PPEndix table 1. Articles Included in 3 Meta-analyses of Diabetes and Pre- and Postoperative Hyperglycemia

\begin{tabular}{|c|c|c|c|c|c|c|c|}
\hline Author & $\begin{array}{l}\text { Study } \\
\text { Year }\end{array}$ & $\begin{array}{l}\text { No. of } \\
\text { Procedures }\end{array}$ & $\begin{array}{l}\text { No. of } \\
\text { SSIs }\end{array}$ & Surgery Type & Diabetes & & $\begin{array}{l}\text { Postoperative } \\
\text { Glucose }\end{array}$ \\
\hline Abdul-Jabbar et $\mathrm{al}^{25}$ & 2012 & 6,628 & 193 & Spinal & $\mathrm{X}$ & & \\
\hline Anthony et $\mathrm{al}^{27}$ & 2011 & 197 & 69 & Elective transabdominal colorectal & $\mathrm{X}$ & & \\
\hline Apisarnthanarak et $\mathrm{al}^{28}$ & 2003 & 60 & 13 & Spinal & $\mathrm{X}$ & & \\
\hline Bachoura et $\mathrm{al}^{29}$ & 2011 & 1,783 & 75 & Orthopaedic trauma & $\mathrm{X}$ & & \\
\hline Bundy et $\mathrm{al}^{32}$ & 2006 & 3,878 & 322 & CABG & $\mathrm{X}$ & & \\
\hline 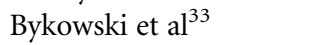 & 2011 & 8,850 & 31 & Elective hand & $\mathrm{X}$ & & \\
\hline Cannon et $\mathrm{al}^{34}$ & 2012 & 9,940 & 1,497 & Elective colorectal resection & $\mathrm{X}$ & & \\
\hline Caputo et $\mathrm{al}^{17}$ & 2013 & 3,138 & 115 & Orthopaedic spine & $\mathrm{X}$ & & $\mathrm{X}$ \\
\hline Chaichana et $\mathrm{al}^{35}$ & 2015 & 401 & 21 & Tumor resection & $\mathrm{X}$ & & \\
\hline Chiang et $\mathrm{al}^{39}$ & 2014 & 416 & 104 & Craniotomy or craniectomy & $\mathrm{X}$ & $\mathrm{X}$ & \\
\hline Chopra et $\mathrm{al}^{40}$ & 2012 & 751 & 91 & Roux-en-Y gastric bypass surgery (RYGBS) & $\mathrm{X}$ & & \\
\hline Chu et $\mathrm{al}^{41}$ & 2015 & 528 & 36 & Stoma reversal & $\mathrm{X}$ & & \\
\hline Chung et $\mathrm{al}^{42}$ & 2015 & 2,899 & 143 & Free flap breast reconstruction & $\mathrm{X}$ & & \\
\hline Coakley et $\mathrm{al}^{43}$ & 2012 & 59 & 16 & Colectomy for fulminant ulcerative colitis (UC) & $\mathrm{X}$ & & \\
\hline Coleman et $\mathrm{al}^{44}$ & 2014 & 77 & 17 & Hysterectomy & $\mathrm{X}$ & & \\
\hline Davies et $\mathrm{al}^{45}$ & 2012 & 268 & 49 & Ventral hernia repair & $\mathrm{X}$ & & \\
\hline deFreitas et $\mathrm{al}^{46}$ & 2012 & 40,669 & 1301 & Elective vascular procedures & $\mathrm{X}$ & & \\
\hline Deierhoi et $\mathrm{al}^{47}$ & 2013 & 5,750 & 709 & Colorectal & $\mathrm{X}$ & & \\
\hline Elfenbein et $\mathrm{al}^{48}$ & 2014 & 49,326 & 179 & Thyroidectomy & $\mathrm{X}$ & & \\
\hline Everhart et $\mathrm{al}^{49}$ & 2012 & 1875 & 29 & Total joint arthroplasty & $\mathrm{X}$ & & \\
\hline Harbarth et $\mathrm{al}^{56}$ & 2000 & 2,641 & 231 & CABG & $\mathrm{X}$ & & \\
\hline Hardy et $\mathrm{al}^{21}$ & 2010 & 114 & 57 & Craniotomy & $\mathrm{X}$ & & $\mathrm{X}$ \\
\hline Harness et $\mathrm{al}^{57}$ & 2010 & 2,336 & 11 & Carpal tunnel release & $\mathrm{X}$ & & \\
\hline Hellinger et $\mathrm{al}^{58}$ & 2011 & 1,036 & 166 & Liver transplantation & $\mathrm{X}$ & & \\
\hline Hendren et $\mathrm{al}^{59}$ & 2013 & 4,331 & 380 & Colectomy & & & $\mathrm{X}$ \\
\hline Jackson et $\mathrm{al}^{60}$ & 2012 & $7,576^{\mathrm{a}} 5,773^{\mathrm{b}}$ & N/A & Colectomy & & $\mathrm{X}$ & $\mathrm{X}$ \\
\hline Jeon et $\mathrm{al}^{22}$ & 2012 & 13,800 & 260 & Any & & $\mathrm{X}$ & $\mathrm{X}$ \\
\hline Kaafarani et $\mathrm{al}^{61}$ & 2010 & 145 & 21 & Ventral hernia repair & $\mathrm{X}$ & & \\
\hline Kalra et $\mathrm{al}^{62}$ & 2013 & 9,006 & 27 & Multiple & $\mathrm{X}$ & & \\
\hline Koutsoumbelis et $\mathrm{al}^{63}$ & 2011 & 3,218 & 84 & Posterior lumbar & $\mathrm{X}$ & $\mathrm{X}$ & $\mathrm{X}$ \\
\hline Kuy et $\mathrm{al}^{64}$ & 2014 & 106 & 33 & Lower extremity revascularization & $\mathrm{X}$ & & \\
\hline
\end{tabular}


APPEndiX table 1. Continued

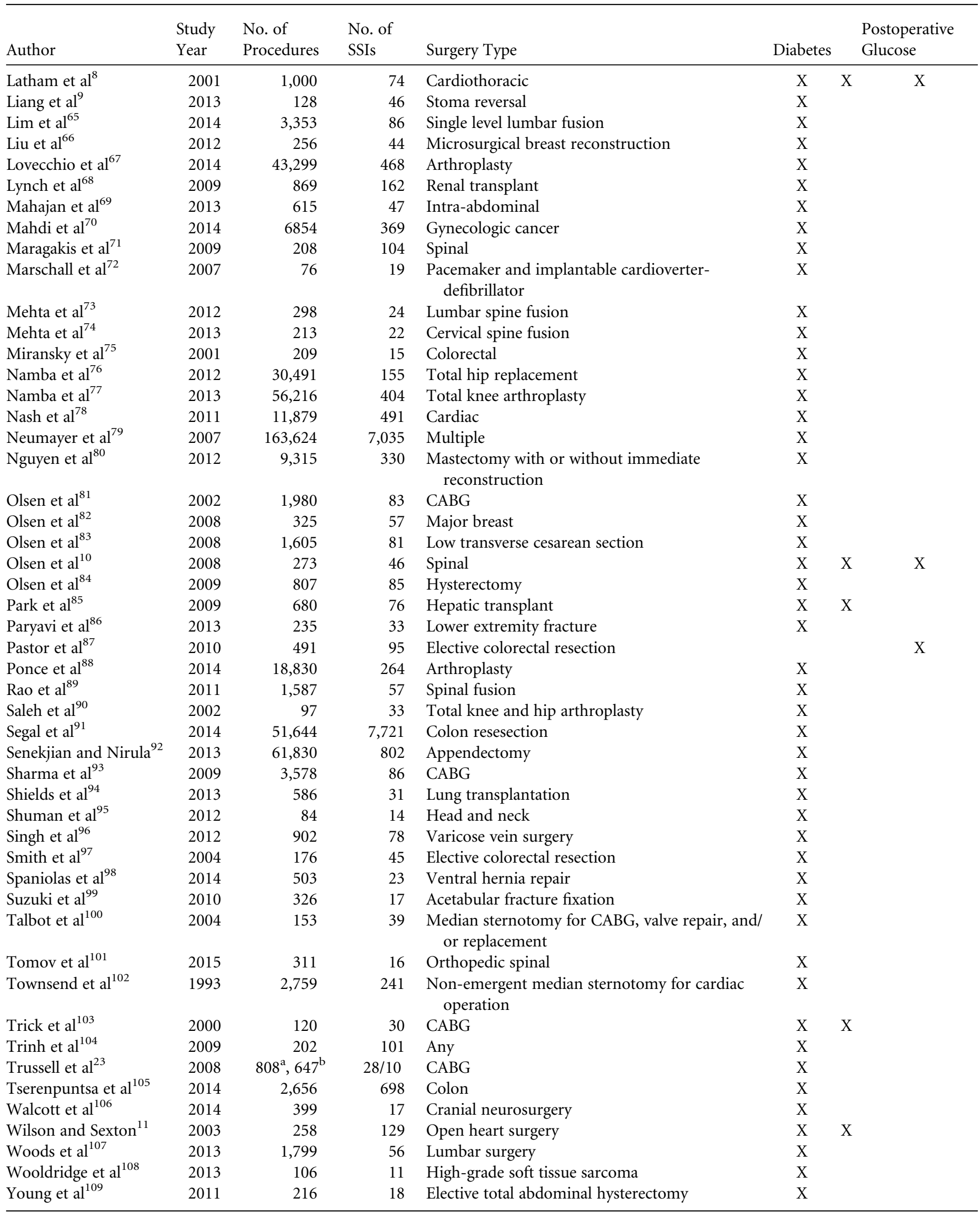

